\title{
Data-based Research on the Relationship between the Share Structure of State-owned Holding Bank and Corporate Performance
}

\author{
Wei Weng \\ Yunnan Normal University \\ Kunming, China \\ vemal@163.com
}

\author{
Jiahui Jiang, Xiaohan Jiang and Lingyan Niu* \\ Yunnan Normal University \\ Kunming, China
}

\begin{abstract}
Taking the joint-stock commercial banks listed on Shanghai and Shenzhen A-shares Exchanges during 2014-2016 as the study samples, this article provides an empirical study on the relationship between the share structure of state-owned holding bank and corporate performance, in which the particularities of the banking industry were fully considered, and multiple regression models established. The research results show that from a perspective of the concentration of stock equity, bank performance is negatively correlated with the proportion of shares held by the biggest shareholder, and equity balance index $\mathrm{Z}$, while positively related to the proportion of shares held by the top ten shareholders. In terms of the nature of stock rights, the state-owned proportion of shares is negatively related to the performance of the bank, while the proportion of shares held by foreign investor for strategic purposes has little influence over the performance of the bank. Therefore, in order to improve the performance of a joint-stock commercial bank, it is recommended that one should start from optimizing the share structure by limiting the state-owned proportion of shares in a proper way and then increase the proportion of shares held by corporate entities, so as to prevent the negative influence by the excessively decentralized distribution of shares on business performance.
\end{abstract}

Keywords: share structure; corporate performance; joint-stock commercial bank; mixed ownership.

\section{INTRODUCTION}

In analyzing share structure, most foreign scholars put their emphasis on the degree of concentration of shares and the nature of stock rights. However, Chinese scholars Ruan Ke, He Yongfang and Liu Danping (2015) put forward that the degree of concentration of shares has a curvilinear relationship with business performance, and that there is a "point of inflexion" which leads to the maximum of performance. Moreover, Li Kan (2013) discovered that the degree of concentration of shares is negatively correlated to the performance of the bank.

In addition to the degree of concentration of shares, some scholars also studied the relationship between the nature of stock rights and business performance, ending up with different conclusions. Duan Junshan and Huang Jianchao (2013) put forward that when the biggest shareholder is a state entity, it will produce a significant and positive influence on the performance of the bank. But Gao Li and Liu Zhaojun (2015) reached a contrary conclusion.
Thus it appears that the relationship between the share structure and bank performance is uncertain. Besides, in different time periods, the factors affecting the performance of the bank vary with changes in capital market and national policies. For this reason, this article sought for a method for improving bank management efficiency by the empirical analysis on the relationship between the share structure of the bank and business performance, which was based on the data of the joint-stock commercial banks listed on Shanghai and Shenzhen A-shares Exchanges during 2014-2016.

\section{THEORETICAL ANALYSIS AND HYPOTHESIS FOR THE STUDY}

\section{A. Influence by the Degree of Concentration of Shares on Bank Performance}

The share structure of a commercial bank influences its management system and thus its management efficiency, and plays a decisive role in its business performance. However, there is still no commonly agreed conclusion regarding the relationship between the degree of concentration of shares of a bank and its performance, which means that concentrated and decentralized distributions of shares, in fact, have different influences on the business performance of a listed bank.

For listed banks, decentralized distribution of shares may make small shareholders reluctant or ineligible to take part in the bank's management and decision making, reducing the possibility for them to expresses their views and opinions, pushing them to focus only on their respective interests, and causing difficulties in reaching consensus on specific issues. This will slow down the decision making process and responses on critical problems, and even cause a loss of rare opportunities, thus impeding the bank's business performance. Thus is obvious that a decentralized distribution of shares, to a certain degree, may reduce the business performance of the bank. Based on this, the following hypothesis to be proved is hereby presented:

H1: The performance of a bank is negatively correlated with the proportion of shares held by the biggest shareholder, and equity balance index $\mathrm{Z}$, while positively related to the proportion of shares held by the top ten shareholders. 


\section{B. Influence by the Nature of Shareholders on Business Performance}

Different shareholders seek for different benefits. This causes a divergence of views on management. For state-entity shareholders, which represent the interests of governments at various levels or of state-owned public institutions, not only economic benefits but also national interests and social benefits will be regarded as important. For most corporate-entity shareholders, the reason for which they became shareholders of the bank is to get economic gains, and they have less involvement in politics and governmental intervention, thus paying more attention to the financial outcomes and long-term profits of the listed bank.

In general, individual shareholders, who mainly are investors from the capital market, hold fewer shares in a more scattered pattern, and they are more concerned about the financial gains and short-term profits from their investments. This means that they have little right to speak in shareholders' meetings of the bank. Therefore, individual shareholders produce very limited influence on the performance of the listed bank. Based on this, the second and third hypotheses to be proved are hereby presented:
H2: For joint-stock commercial banks, the proportion of state-owned shares has a negative influence on the bank's performance.

H3: The proportion of shares held by strategic investors has a positive influence on the bank's performance.

\section{Research Design and Selection of Variables}

Eight Chinese joint-stock commercial banks listed on Shanghai and Shenzhen A-shares exchanges during 2014-2016 were selected as the samples. Multiple regression models were established. A half year of data regarding the eight banks was selected. The capacity of sample was 48 . As the purpose of this article was to study the relationship between the share structure of state-owned holding bank and corporate performance, the equity mix variable was taken as the independent variable and performance variable as the dependent variable, and the corresponding control variable was also set. The multiple linear regression models of return on total assets (ROA) and Tobin's Q (TQ) were established as follows:

$$
\begin{aligned}
& R O A=\alpha+\beta_{11} C R_{1}+\beta_{12} \mathrm{Z}+\beta_{13} C R 10+\beta_{14} S P P+\beta_{15} \text { Outshare }+\beta_{16} F N+\beta_{17} T A+\varepsilon_{1} \\
& T Q=\alpha+\beta_{21} C R_{1}+\beta_{22} \mathrm{Z}+\beta_{23} C R 10+\beta_{24} S P P+\beta_{25} \text { Outshare }+\beta_{26} F N+\beta_{27} T A+\varepsilon_{2}
\end{aligned}
$$

Where ROA and TQ are the performance variable of the bank; ROA represents accounting data; TQ indicates the market value of the bank. CR1, Z, CR10, SPP, Outshare and FN are the equity mix variables which represent the proportion of shares held by the biggest shareholder, the ratio of the proportion of outstanding shares held by the biggest shareholder to the proportion of outstanding shares held by the second big shareholder, the total proportion of shares held by the top ten shareholders, the proportion of state-owned shares, the proportion of shares held by foreign corporations, and the dummy variable showing whether the joint-stock commercial bank is held and controlled by a state-owned entity, respectively. TA, the control variable, is the natural logarithm of the total assets of the bank. $\alpha$ represents the constant; $\beta 1-\beta 7$ represents the variation coefficients; and $\varepsilon$ is the residual.

The descriptive statistics for studying the variables were calculated by Eviews software based on the semi-annual data of the eight state-owned holding banks during 2014-2016. From the results of the descriptive statistics we can observe that there is significant difference in the performance of state-owned holding banks, and TQ was fluctuating between 19.5313 and 0.7710 (a fairy wide range). However, the standard deviation is small, and the difference in ROA was insignificant, which shows that the state-owned holding banks were running steadily, except for some banks which are extreme cases. The equity concentration indexes-CR1 and CR10, are fluctuating between a wide range with a big standard deviation. In terms of the nature of stock rights, the state-owned holding banks were almost the same.

\section{EMPIRICAL ANALYSIS}

The regression results of the models in which ROA represents the performance of the joint-stock commercial banks are showed in Table 1, from which it can be seen that the regression fitting degree $\mathrm{R} 2=0.93541$ is close to 1 , meaning a good equation fitting effect. From the variable regression coefficient we can see that the increase in the proportion of shares held by the biggest shareholder, $\mathrm{Z}$ index, the proportion of state-owned shares, and the proportion of shares held by strategic investors causes the reduction of ROA. This meets the three hypotheses mentioned above. However, the shares held by strategic investors do not satisfy $10 \%$ confidence level; the increase in the proportion of the top ten shares leads to the increase in ROA and it satisfies $10 \%$ confidence level; and the increase in control variable - the bank's total assets results in the increase of the profit rate of the bank.

The regression results of the models in which TQ represents the performance of the joint-stock commercial banks are showed in Table 2. In a similar way, the egression fitting degree $\mathrm{R} 2$ is close to 1 , showing a good equation fitting effect, and the results are credible. The increase in the proportion of shares held by the biggest shareholder, $\mathrm{Z}$ index, and the proportion of state-owned shares results in a decrease in TQ, and $10 \%$ confidence level is satisfied; the increase in the proportion of shares held by strategic investors leads to the increase of TQ, and $10 \%$ confidence level is satisfied. The increase in control variable - the bank's total assets results in the increase of the profit rate of the bank. 
Based on the aforementioned results it can be see that from a perspective of the degree of concentration of stock rights of a joint-stock bank, the proportion of shares held by the biggest shareholder and equity balance index $\mathrm{Z}$ are negatively correlated to the bank's performance, while the proportion of shares held by the ten top shareholders is positively correlated to the bank's performance, which meets H1. From a perspective of the nature of stock rights of a joint-stock bank, the proportion of state-owned shares produced a negative influence on the banks' performance, which meets $\mathrm{H} 2$. The proportion of shares held by strategic investors produced insignificant influence on the bank's performance, which does not meet $\mathrm{H} 3$.

TABLE 1 ROA MULTIPLE LINEAR REGRESSION RESULTS

\begin{tabular}{|c|c|c|c|c|}
\hline Variable & Coefficient & Standard error & t vale & $\mathrm{p}$ vale \\
\hline CR1 & -0.013890 & 0.568665 & 3.67594 & 0.0367 \\
\hline Z & -0.011553 & 0.258417 & 3.265146 & 0.0030 \\
\hline CR10 & 0.012152 & 0.125895 & 7.598412 & 0.0546 \\
\hline SSP & -0.12484 & 0.361761 & 2.357481 & 0.0128 \\
\hline Outshare & -0.02152 & 0.567632 & 2.254481 & 0.1246 \\
\hline FN & 0.059498 & 0.034337 & 4.937259 & 0.0254 \\
\hline TA & 0.079321 & 0.057592 & 3.368488 & 0.0000 \\
\hline $\mathrm{C}$ & 0.268338 & 0.025489 & 3.598441 & 0.0000 \\
\hline $\mathrm{R} 2$ & 0.93541 & & & \\
\hline $\mathrm{SC}$ & 2.01056 & & & \\
\hline AIC & 1.958742 & & & \\
\hline $\mathrm{F}$ & 108.1131 & & & \\
\hline DW & 1.596332 & & & \\
\hline TABLE 2 & \multicolumn{4}{|c|}{ TQ MULTIPLE LINEAR REGRESSION RESULTS } \\
\hline Variable & Coefficient & Standard error & $\mathrm{t}$ vale & $\mathrm{p}$ vale \\
\hline CR1 & -0.009890 & 0.970669 & 3.68594 & 0.0198 \\
\hline $\mathrm{Z}$ & -0.001596 & 0.059157 & 2.523146 & 0.0000 \\
\hline CR10 & 0.013662 & 0.082305 & 7.869685 & 0.0150 \\
\hline SSP & -0.12634 & 0.066761 & 3.319991 & 0.0033 \\
\hline Outshare & 0.00342 & 0.667691 & 3.68768 & 0.0712 \\
\hline FN & 0.000498 & 0.034225 & 4.937927 & 0.1256 \\
\hline TotalAsset & 0.07932 & 0.057660 & 3.802688 & 0.0000 \\
\hline $\mathrm{C}$ & 0.015338 & 0.004429 & 3.463441 & 0.0012 \\
\hline R2 & 0.946962 & & & \\
\hline $\mathrm{SC}$ & 2.447262 & & & \\
\hline AIC & 2.250920 & & & \\
\hline $\mathrm{F}$ & 119.0191 & & & \\
\hline DW & 1.278014 & & & \\
\hline
\end{tabular}

\section{SOLUTIONS AND RECOMMENDATIONS}

This article has discussed in detail the relationship between the share structure and the performance. A reasonable share structure can constantly improve the performance of banks while an unreasonable share structure will impede the development of banks. Therefore, to improve the performance of joint-stock commercial banks, it should be start from optimizing their share structures. The concrete measures are as follows: (I) reduce the proportion of state-owned shares in a proper manner and increase the proportion of shares held by corporations; and foster competent state-entity shareholders; (II) reduce the degree of concentration of stock rights; (III) support diversification of investors; (IV) establish an effective external safeguard mechanism.

Based on the conclusion of the empirical analysis, this article has proved the positive influence by the mixed-ownership reform on the state-owned holding banks. Therefore, state-owned holding banks should be active in implementing the mixed-ownership reform to reduce the proportion of state-owned shares, bring in strategic investors, and increase the proportion of shares held by corporation, so as to form a multi-layer and diversified share structure.

\section{REFERENCES.}

[1] Ruan Ke, He Yongfang, Liu Danping, Diversified Operation and Performance-Based on the Empirical Research on 2004-2013 Panel Data of Listed Chinese Commercial Banks 2004-2013, [J] Macroeconomics, 2015(11):142-151.

[2] Li Kan, Empirical Analysis on Management and Performance of Commercial Banks, [J] Finance Forum, 2013,18(05):28-34.

[3] Duan Junshan, Huang Jianchao, Bank Management, Salaries of Senior Managers and Bank Performance. [J] Finance Forum, 2013,18(08):36-46.

[4] Gaoli and Liu Zhaojun, Mixed Ownership, Capital Structure and Bank Performance $[\mathrm{J}]$, Finance and Accounting Monthly, 2015(17):107-110. 